\title{
Induction of protective immunity against larval Onchocerca volvulus in a mouse model.
}

\author{
A. M. Lange \\ Thomas Jefferson University \\ W. Yutanawiboonchai \\ Thomas Jefferson University \\ J. B. Lok \\ University of Pennsylvania
}

M. Trpis

Johns Hopkins University

D. Abraham

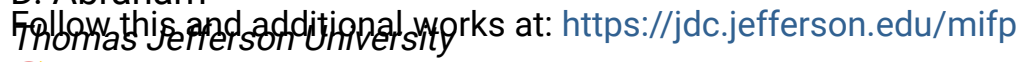

Part of the Medicine and Health Sciences Commons

Let us know how access to this document benefits you

\section{Recommended Citation}

Lange, A. M.; Yutanawiboonchai, W.; Lok, J. B.; Trpis, M.; and Abraham, D., "Induction of protective immunity against larval Onchocerca volvulus in a mouse model." (1993). Department of Microbiology and Immunology Faculty Papers. Paper 138.

https://jdc.jefferson.edu/mifp/138

This Article is brought to you for free and open access by the Jefferson Digital Commons. The Jefferson Digital Commons is a service of Thomas Jefferson University's Center for Teaching and Learning (CTL). The Commons is a showcase for Jefferson books and journals, peer-reviewed scholarly publications, unique historical collections from the University archives, and teaching tools. The Jefferson Digital Commons allows researchers and interested readers anywhere in the world to learn about and keep up to date with Jefferson scholarship. This article has been accepted for inclusion in Department of Microbiology and Immunology Faculty Papers by an authorized administrator of the Jefferson Digital Commons. For more information, please contact: JeffersonDigitalCommons@jefferson.edu. 


\title{
INDUCTION OF PROTECTIVE IMMUNITY AGAINST LARVAL ONCHOCERCA VOLVULUS IN A MOUSE MODEL
}

\author{
ANNA MARIE LANGE, WIBOONCHAI YUTANAWIBOONCHAI, JAMES B. LOK, \\ MILAN TRPIS, AND DAVID ABRAHAM \\ Department of Microbiology and Immunology, Thomas Jefferson University, Philadelphia, \\ Pennsylvania; Department of Pathobiology, University of Pennsylvania, Philadelphia, \\ Pennsylvania; Department of Immunology and Infectious Diseases, The Johns Hopkins University, \\ Baltimore, Maryland
}

\begin{abstract}
BALB/cBYJ mice were immunized against larval Onchocerca volvulus by subcutaneous injection of normal, irradiated, or freeze-thaw-killed Onchocerca sp. larvae. The mice received challenge infections of $O$. volvulus third-stage larva $\left(\mathrm{L}_{3}\right)$ contained in diffusion chambers implanted subcutaneously. At two-weeks postinfection, the diffusion chambers were removed and larval survival was assessed. When mice were immunized a single time with 35-krad-irradiated or normal $O$. volvulus $\mathrm{L}_{3}$, there was a significant reduction in the survival of challenge parasites. However, there was little or no reduction in challenge worm survival when mice were immunized a single time with freeze-thaw-killed $O$. volvulus $\mathrm{L}_{3}$ or fourth-stage larva $\left(\mathrm{L}_{4}\right)$, or irradiated $O$. lienalis $\mathrm{L}_{3}$. When a second dose of freeze-thaw killed $O$. volvulus $\mathrm{L}_{3}$ or irradiated $O$. lienalis $\mathrm{L}_{3}$ was administered, there was a significant reduction in parasite survival in immunized mice. Immunization with $O$. volvulus $\mathrm{L}_{4}$ or a combination of $\mathrm{L}_{3}$ and $\mathrm{L}_{4}$ failed to confer protection. These results demonstrate that mice can be immunized against larval $O$. volvulus and that diffusion chambers are an efficient method for studying protective immunity to this parasite in a mouse model.
\end{abstract}

Studies on the induction and mechanisms of protective immunity to Onchocerca spp. have focused largely on responses to microfilariae (mf). It has been shown that mice can be immunized against infection with $\mathrm{mf}$ of $O$. lienalis by previous sensitization with normal living $\mathrm{mf} .^{1}{ }^{12} \mathrm{Re}-$ sistance to infection with $\mathrm{mf}$ can be passively transferred with serum from immunized mice or by transferring a combination of immune $\mathrm{T}$ and B cells. ${ }^{3}$ Mice immunized against $O$. lienalis $\mathrm{mf}$ were also shown to be resistant to infection with $\mathrm{mf}$ of $O$. volvulus. ${ }^{4}$ While the study of protective immunity to $\mathrm{mf}$ may be of importance in understanding the pathogenesis of onchocerciasis, the development of vaccines against the infection will depend on a thorough knowledge of immune responses to the infective third-stage larvae $\left(\mathrm{L}_{3}\right)^{.5}$

Animal models available for studying immunity to the $\mathrm{L}_{3}$ of $O$. volvulus are extremely limited. Natural animal reservoir hosts for this infection have not been identified and only rare infections of nonhuman primates in the wild have been reported. ${ }^{6}$ Chimpanzees and mangabey monkeys have been experimentally infected with $O$. volvulus $\mathrm{L}_{3} \cdot{ }^{6-10}$ Although infections reach patency in chimpanzees and mangabey monkeys, it is unlikely that these animals could be used for large-scale study of protective immunity to $O$. volvulus due to the prohibitive cost and strict regulations associated with their use. Therefore, there is a need for small animal models to study immune-mediated resistance to $\mathrm{L}_{3}$ of $O$. volvulus and to screen antigens as potential vaccine candidates.

All attempts to recover Onchocerca spp. larvae from small laboratory animals following infection have failed. ${ }^{11-13}$ However, Onchocerca spp. larvae contained in diffusion chambers can be recovered from various rodent hosts for extended periods of time. ${ }^{14-17}$ Survival and development of $O$. volvulus $\mathrm{L}_{3}$ in diffusion chambers implanted in mice were equivalent to that seen in primates. ${ }^{17}$ The diffusion chamber technique has been used successfully to contain various filarial worms for immunologic studies in both natural and alternative host systems. ${ }^{16}$. $18-22$ In addition to ensuring accurate recovery of challenge larvae, this method makes it possible to distinguish challenge worms from persisting live immunization worms.

Vaccination against infection using radiationattenuated parasites has been used successfully against the filarial worms Brugia malayi, ${ }^{21,23,24}$ Dirofilaria immitis, ${ }^{20 .}{ }^{25}$ B. pahangi, 23. 26. 27 Acan- 
thocheilonema viteae, ${ }^{28}$ and Litomosoides carinii. ${ }^{29}$ Immunization of mice with irradiated $O$. lienalis $\mathrm{L}_{3}$ significantly reduced challenge infections of larvae contained within diffusion chambers. ${ }^{16}$ The levels of protection elicited with irradiated filarial vaccines were consistently higher than those seen using other parasite preparations; however, the exact reasons for this superiority are unclear. ${ }^{30}$ While the radiation dose used to attenuate the immunizing parasites was a critical factor, the optimal radiation dose varied depending upon the parasite system.

The objectives of this study were to demonstrate that protective immunity against $O$. volvulus larvae could be induced in a mouse model and to determine which parasite components are necessary for that induction. It was found that mice can be immunized against larval $O$. volvulus using normal $O$. volvulus $\mathrm{L}_{3}$ or $O$. volvulus $\mathrm{L}_{3}$ that were irradiated at a wide range of dosages. Vaccination with dead $O$. volvulus $\mathrm{L}_{3}$ or irradiated $O$. lienalis $\mathrm{L}_{3}$ was also effective in inducing immunity when a booster dose was administered. However, preparations containing fourth-stage larva $\left(L_{4}\right)$ failed to confer protection.

\section{MATERIALS AND METHODS}

\section{Animals}

Male BALB/cByJ mice were obtained from Jackson Laboratories (Bar Harbor, ME). Mice were between six and 12 weeks of age at the start of the experiment.

\section{Antigen preparations}

Cryopreserved $\mathrm{L}_{3}$ were prepared in Liberia. Briefly, pupae of Simulium yahense were collected in the field and reared to adults in the laboratory. The flies were fed on $O$. volvulusinfected donors and after seven days, $L_{3}$ were collected and cryopreserved in dimethyl sulfoxide and sucrose using Biocool II computerized freezing equipment (FTS Systems Inc, Stone Ridge, NY). Cryopreserved $O$. lienalis $\mathrm{L}_{3}$ were prepared as previously described. ${ }^{16}$ The $L_{3}$ were defrosted as previously described ${ }^{16.17}$ and placed in a 1:1 ( $v / v)$ mixture of National Cancer Institute Tissue Culture Medium 135 and Iscove's modified Dulbecco's media containing $100 \mathrm{U} / \mathrm{ml}$ of penicillin/streptomycin and $10 \mu \mathrm{g} / \mathrm{ml}$ of gentamicin (Sigma, St. Louis, MO). Larvae were ir- radiated at different doses by exposure to $x$-rays using an orthovoltage $x$-ray unit (Siemens, Erlangen, Germany). Fourth-stage larvae were prepared by implanting subcutaneously in mice diffusion chambers containing $O$. volvulus $\mathrm{L}_{3}$ for nine days. It was previously demonstrated that O. volvulus $\mathrm{L}_{3}$ molt to $\mathrm{L}_{4}$ 3-7 days after implantation in vivo in diffusion chambers. ${ }^{17}$ Dead $\mathrm{L}_{3}$ or $\mathrm{L}_{4}$ were prepared for immunization by freezing and thawing larvae five times on dry ice and in a $37^{\circ} \mathrm{C}$ water bath.

\section{Experimental protocol}

Mice were immunized by injecting 50 larvae subcutaneously into the nape of the neck for the primary immunization, followed two weeks later by 25 larvae for the second immunization, unless otherwise noted. Three weeks after the initial immunization, animals received challenge infections consisting of $25 \mathrm{O}$. volvulus $\mathrm{L}_{3}$ implanted subcutaneously within diffusion chambers. Experiments were terminated two weeks postchallenge to allow sufficient time for challenge $\mathrm{L}_{3}$ to develop into $L_{4}$, thereby giving the host two larval targets for the immune response to attack. ${ }^{17}$ Mice were killed by exsanguination under methoxyflurane (Pitman-Moore Inc., Mundelein, IL), diffusion chambers were removed, and larvae were recovered. Actively motile larvae with good structural integrity were counted as live and were then fixed in $70 \%$ alcohol containing $5 \%$ glycerine at $60^{\circ} \mathrm{C}$. Larval lengths were measured using projected images in the Macmeasure image analysis system (Research Services Branch, National Institute of Mental Health, Bethesda, MD).

\section{Statistical analysis}

All data were analyzed by multivariate general linear hypothesis multifactorial analysis of variance using Systat 5.2 (Systat, Evanston, IL). Probability values of less than 0.05 were considered significant. The percent reduction was calculated as follows: \% Reduction $=[$ (Mean control mouse worm survival - Mean immunized mouse worm survival) $\div$ Mean control worm survival] $\times 100$.

\section{RESULTS}

Onchocerca volvulus $\mathrm{L}_{3}$ were $\mathrm{x}$-irradiated in doses ranging from 5 to $85 \mathrm{krad}$ and implanted 
TABLE 1

In vivo survival and development of $x$-irradiated Onchocerca volvulus infective third-stage larvae $\left(L_{3}\right)$ contained in diffusion chambers that were implanted in mice for two weeks*

\begin{tabular}{|c|c|c|c|c|c|c|c|}
\hline \multirow{2}{*}{$\begin{array}{l}\text { Radiation } \\
\text { dose (krad) }\end{array}$} & \multirow{2}{*}{$\begin{array}{c}\text { No. of } \\
\text { mice }\end{array}$} & \multirow{2}{*}{$\begin{array}{c}\% \text { live } \\
\text { recovery } \\
\text { (mean } \pm \text { SD) }\end{array}$} & \multirow{2}{*}{$\begin{array}{l}\text { No. of } \\
\text { worms }\end{array}$} & \multirow{2}{*}{$\underset{(\operatorname{mean} \pm \text { SD) } \dagger}{\text { Length, } \mu \mathrm{m}}$} & \multicolumn{3}{|c|}{ Stape } \\
\hline & & & & & $\% L_{3}$ & $\% L_{3} / L_{4}$ & $\% \mathrm{~L}$ \\
\hline 0 & 3 & $24 \pm 14$ & 15 & $509 \pm 86$ & 7 & 40 & 53 \\
\hline 5 & 3 & $23 \pm 8$ & 16 & $478 \pm 66$ & 0 & 25 & 75 \\
\hline 15 & 3 & $24 \pm 14$ & 14 & $536 \pm 71$ & 14 & 43 & 43 \\
\hline 25 & 3 & $21 \pm 13$ & 12 & $595 \pm 49$ & 0 & 0 & 100 \\
\hline 35 & 3 & $28 \pm 24$ & 13 & $496 \pm 61$ & 23 & 46 & 31 \\
\hline 45 & 2 & $22 \pm 3$ & 8 & $470 \pm 58$ & 0 & 63 & 37 \\
\hline 55 & 2 & $36 \pm 28$ & 14 & $454 \pm 70$ & 7 & 50 & 43 \\
\hline 65 & 3 & $27 \pm 6$ & 12 & $488 \pm 67$ & 8 & 67 & 25 \\
\hline 75 & 3 & $12 \pm 14$ & 8 & $576 \pm 99$ & 13 & 38 & 50 \\
\hline 85 & 2 & $6 \pm 3$ & 3 & $472 \pm 19$ & 0 & 67 & 33 \\
\hline
\end{tabular}

* Larvae that had formed the fourth-stage $\left(L_{4}\right)$ cuticle, but had not yet shed the $L_{3}$ cuticle, were classified as $L_{3} / L_{\text {. }}$.

$t$ Length of $L_{3}=497 \pm 96 \mu \mathrm{m}$.

in diffusion chambers in naive mice to assess the development of radiation-attenuated worms in vivo. After two weeks, the diffusion chambers were removed and larval survival and development were assessed. Larval survival of approximately $25 \%$ was found in all groups, except for larvae irradiated with 75 and $85 \mathrm{krad}$, for which survival rates decreased to $12 \%$ and $6 \%$, respectively (Table 1 ). The lengths of recovered worms were not significantly different among groups; however, the percentage of larvae completing the molt to $L_{4}$ varied. By two weeks after implantation, all worms irradiated with $25 \mathrm{krad}$

TABLE 2

Effect of immunization of $B A L B / C B Y J$ mice with Onchocerca volvulus infective third-stage larvae $\left(L_{3}\right)$, $x$-irradiated at various dosages, on the survival of challenge larvae implanted in diffusion chambers subcutaneously

\begin{tabular}{|c|c|c|c|c|}
\hline & $\begin{array}{l}\text { Dose of } \\
\text { irradi- } \\
\text { ation } \\
\text { (krad) } \\
\text { per } L_{3}\end{array}$ & $\begin{array}{l}\text { No. of } \\
\text { mice }\end{array}$ & $\begin{array}{c}\% \text { live } \\
\text { recovery } \\
\text { (mean } \pm \text { SD) }\end{array}$ & $\begin{array}{l}\% \\
\text { reduc- } \\
\text { tion }\end{array}$ \\
\hline Experiment 1 & $\begin{array}{l}\text { Control } \\
5 \\
15 \\
25 \\
35 \\
45 \\
55 \\
65 \\
75 \\
85\end{array}$ & $\begin{array}{l}5 \\
5 \\
5 \\
3 \\
5 \\
4 \\
5 \\
3 \\
5 \\
5\end{array}$ & $\begin{aligned} 38 & \pm 11 \\
18 & \pm 12 \\
13 & \pm 2 \\
25 & \pm 12 \\
7 & \pm 7 \\
21 & \pm 5 \\
14 & \pm 11 \\
16 & \pm 11 \\
18 & \pm 5 \\
23 & \pm 7\end{aligned}$ & $\begin{array}{l}- \\
53^{*} \\
66^{*} \\
34 \\
82^{*} \\
45^{*} \\
63^{*} \\
58^{*} \\
53^{*} \\
39^{*}\end{array}$ \\
\hline Experiment 2 & $\begin{array}{l}\text { Control } \\
25 \\
35 \\
45\end{array}$ & $\begin{array}{l}5 \\
5 \\
5 \\
5\end{array}$ & $\begin{array}{r}34 \pm 8 \\
22 \pm 8 \\
14 \pm 9 \\
9 \pm 9\end{array}$ & $\begin{array}{l}- \\
35^{*} \\
59^{*} \\
74^{*}\end{array}$ \\
\hline
\end{tabular}

had completed the molt to $\mathrm{L}_{4}$, while approximately one-quarter of the surviving 35-krad-irradiated larvae remained $L_{3}$. Overall, regardless of the irradiation dose, the majority of larvae recovered after two weeks had either synthesized the $\mathrm{L}_{4}$ cuticle but had not yet completed the molt to $\mathrm{L}_{4}\left(\mathrm{~L}_{3} / \mathrm{L}_{4}\right)$ or they had successfully molted to the $\mathrm{L}_{4}$ (Table 1 ).

Onchocerca volvulus $\mathrm{L}_{3}$ were $\mathrm{x}$-irradiated in dosages ranging from 5 to $85 \mathrm{krad}$ and were then used to vaccinate mice using a single immunization of $50 \mathrm{~L}_{3}$ per mouse. Immunization resulted in reductions in challenge parasite survival ranging from $34 \%$ to $82 \%$ in all groups of immunized mice (Table 2, experiment 1). The greatest reduction was seen in mice vaccinated with 35-krad-irradiated $L_{3}$, while the least re-

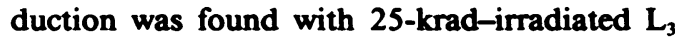
vaccination. Mice were then immunized with either 25-, 35-, or 45-krad-irradiated larvae. Significant reductions in challenge larval survival was observed in all of the immunized groups (Table 2, experiment 2). Because the 35-kradirradiated $\mathrm{L}_{3}$ immunization consistently induced a significant level of protective immunity, this immunization protocol was chosen for further study.

Mice were immunized with initial doses of 10 150 35-krad-irradiated $L_{3}$, followed in some cases by a second immunization of 25 irradiated $L_{3}$ (Table 3). A minimum of dose of $25 \mathrm{~L}_{3}$ was needed to confer a significant level of protection. The greatest reduction in worm survival was seen in mice receiving an initial dose of 50 irradiated larvae, followed by a second dose of $25 \mathrm{~L}_{3}$ two weeks later. Increasing the initial immunizing 
TABle 3

Determination of the optimal primary dose and the effect of a booster inoculation on the induction of protective immunity in mice by 35-krad-irradiated Onchocerca volvulus infective third-stage larvae (L)

\begin{tabular}{ccccc}
\hline $\begin{array}{c}\text { Primary } \\
\text { dose }\end{array}$ & $\begin{array}{c}\text { Booster } \\
\text { dose }\end{array}$ & $\begin{array}{c}\text { No. of } \\
\text { mice }\end{array}$ & $\begin{array}{c}\text { \% live } \\
\text { recovery } \\
\text { (mean } \pm \text { SD) }\end{array}$ & $\begin{array}{c}\text { \% re- } \\
\text { duction }\end{array}$ \\
\hline Control & - & 11 & $40 \pm 9$ & - \\
10 & - & 6 & $45 \pm 7$ & 0 \\
25 & - & 6 & $23 \pm 13$ & $43^{*}$ \\
50 & - & 4 & $21 \pm 8$ & $48^{*}$ \\
50 & 25 & 5 & $14 \pm 8$ & $65^{*}$ \\
100 & 25 & 5 & $26 \pm 8$ & $35^{*}$ \\
150 & 25 & 5 & $28 \pm 11$ & $30^{*}$ \\
\hline$-P<0.05$. & & & &
\end{tabular}

dose above $50 \mathrm{~L}_{3}$ did not result in a further reduction in challenge worm survival (Table 3 ).

At the termination of the irradiated larvae vaccine trials, surviving larvae were collected from diffusion chambers and their lengths were determined. There was no consistent difference in length between worms recovered from immunized animals compared with those collected from control animals.

Various methods of vaccine preparation from Onchocerca spp. larvae were compared with 35krad-irradiated $O$. volvulus $\mathrm{L}_{3}$ for their ability to induce protection against larval $O$. volvulus. Immunization with a single dose of normal, unirradiated $O$. volvulus $\mathrm{L}_{3}$ induced a significant level of protection. Immunization with a single dose of dead $O$. volvulus $\mathrm{L}_{3}$ or $15-\mathrm{krad}$-irradiated $O$. lienalis $\mathrm{L}_{3}$ had no significant effect on challenge worm survival. However, when booster doses of dead $O$. volvulus $\mathrm{L}_{3}$ or 15 -krad-irradiated $O$. lienalis $\mathrm{L}_{3}$ were given, there was a significant decrease in challenge worm survival. Immunizations using killed $O$. volvulus $\mathrm{L}_{4}$ or a combination of $L_{3}$ and $L_{4}$ were not effective in inducing protective immunity (Table 4 ).

\section{DISCUSSION}

In the present study, radiation-attenuated larvae were chosen for initial attempts at immunization of mice against larval $O$. volvulus because of the successes of irradiated vaccines against filaria in the past. ${ }^{16,20,21,23-29}$ Dogs have been protected against infection with $D$. immitis by immunization with $20-k r a d-i r r a d i a t e d ~ L_{3}$. This dose of radiation caused the larvae to develop into sterile, stunted adults. ${ }^{25}$ If greater than
TABLE 4

Effect of immunization of mice with normal, irradiated, and killed Onchocerca volvulus infective third-stage larvae $\left(L_{3}\right)$ and/or fourth-stage larvae ( $\left.L_{1}\right)$ and irradiated Onchocerca lienalis $L_{3}$ on the survival of $O$. volvulus $L_{3}$ implanted in diffusion chambers. Mice were immunized either a single time or received a booster immunization*

\begin{tabular}{lrcc}
\hline $\begin{array}{c}\text { Treatment, } \\
\text { species, and } \\
\text { stage of } \\
\text { immunizing } \\
\text { larvae }\end{array}$ & $\begin{array}{c}\text { No. of } \\
\text { mice }\end{array}$ & $\begin{array}{c}\text { No. of } \\
\text { doses }\end{array}$ & $\begin{array}{c}\% \\
\text { reduction }\end{array}$ \\
\hline O. volvulus & & & \\
Normal $\mathrm{L}_{3}$ & 8 & 1 & $54 \dagger$ \\
35 krad L & 9 & 1 & $60 \dagger$ \\
Dead $\mathrm{L}_{3}$ & 16 & 2 & $67 \dagger$ \\
& 5 & 1 & 14 \\
Dead $\mathrm{L}_{4}$ & 15 & 2 & $67 \dagger$ \\
Dead $\mathrm{L}_{3} / \mathrm{L}_{4}$ & 4 & 1 & 3 \\
& 5 & 1 & 0 \\
O. lienalis $\mathrm{L}_{3}$ & 3 & 2 & 0 \\
15 krad & 5 & 1 & 17 \\
& 9 & 2 & $42 \dagger$ \\
\hline
\end{tabular}

* Data are the combined results from four experiments; values listed are the percent reductions obtained when the immunized groups were compared with the control group in a particular experiment.

$+P<0.05$.

$20 \mathrm{krad}$ was used to attenuate the immunizing larvae, the immunizing worms died prematurely; immunization with these larvae failed to protect dogs against the infection. This finding suggests that the development of immunizing larvae to $\mathrm{L}_{4}$ or adult worms is a requirement for effective immunization of dogs against $D$. immitis. For successful immunization of rats against $L$. carinii, immunizing larvae must be attenuated by radiation dosages greater than $\mathbf{4 0} \mathrm{krad}$. If immunizing $L$. carinii $\mathrm{L}_{3}$ were irradiated with less than $40 \mathrm{krad}$, they failed to confer protection. ${ }^{29}$ Irradiation with $40 \mathrm{krad}$ prevented $L_{3}$ from molting to $\mathrm{L}_{4}$. This finding suggests that in the $L$. carinii system, prolonged exposure to $L_{3}$ is required for the induction of protective immunity. Therefore, to develop immunity against some parasites, such as $D$. immitis, it is important for the host to be exposed to more than one stage, whereas for others, such as $L$. carinii, prolonged exposure to a single stage is crucial.

In the present experiments, protective immunity was seen in mice vaccinated with irradiated $L_{3}$, regardless of the radiation dose used to attenuate the larvae. In vivo, irradiated $O$. volvulus larvae in diffusion chambers survived and developed to approximately the same degree 
regardless of the radiation dosage used. These findings suggest that for $O$. volvulus, unlike the examples mentioned above, the dose of radiation used to irradiate immunizing larvae is not a critical factor in determining whether a vaccine will induce a significant level of parasite killing. This successful immunization of mice with irradiated larvae appears to conflict with a study in which chimpanzees immunized with 45-krad-irradiated $O$. volvulus failed to develop protective immunity. ${ }^{31}$ The experimental protocols used in the chimpanzee study and in the present mouse study differ in the timing and dosage of the immunizations, making comparisons between these two studies difficult. The criterion used for vaccine efficacy in the chimpanzee study was the absence of $\mathrm{mf}$ in the skin of immunized animals. It is possible that protective immunity would have been recognized in the chimpanzee study if the presence or absence of live larvae or adults had been used as the criteria for vaccine success.

Killed parasite vaccines have induced protective immunity in other filarial systems. ${ }^{18,32,33}$ In the present experiments, a single injection of 50 killed $O$. volvulus $\mathrm{L}_{3}$ did not produce immunity to challenge. However, two immunizations with killed $O$. volvulus $\mathrm{L}_{3}$ were able to confer resistance to infection comparable with that seen with irradiated larvae. Immunization with killed $\mathrm{L}_{4}$, however, did not induce protective immunity. Therefore, exposure to larval excretory/secretory antigens or $\mathrm{L}_{4}$-specific antigens does not appear to be required for the development of protective immunity against larval $O$. volvulus in the mouse. Induction of protective immunity was dependent upon the presence of $L_{3}$ antigens and the dose and timing of the immunizations.

Immunization of mice in the present study with irradiated $O$. lienalis $\mathrm{L}_{3}$ was capable of producing a significant reduction in the survival of challenge $O$. volvulus larvae. The dose of irradiation used on the immunizing $O$. lienalis larvae was based on the optimal dose found for homologous immunization and challenge. ${ }^{16}$ Crossspecies protection between filarial parasite species has been demonstrated with Onchocerca spp. $\mathrm{mf}^{4}$ and Brugia spp. $\mathrm{L}_{3} \cdot{ }^{33}$

Growth retardation of challenge larvae has been reported in studies of protective immunity in $D$. viteae, ${ }^{19} B$. malayi, ${ }^{21}$ and $D$. immitis. ${ }^{34}$ Immunity induced against $O$. volvulus by $35-\mathrm{krad}-\mathrm{ir}-$ radiated $O$. volvulus $\mathrm{L}_{3}$ was not associated with a decrease in the length of challenge worms. A possible explanation for this finding is that there was great variability in the lengths of the $L_{3}$, as has been previously reported. ${ }^{35}$ This variability may have overshadowed any differences caused by the immune response.

In conclusion, these studies demonstrate that protective immunity to larval $O$. volvulus can be induced in mice using live, dead or radiationattenuated $O$. volvulus $\mathrm{L}_{3}$ or irradiated $O$. lienalis $L_{3}$. The model developed in the present study can be a valuable tool for the screening of antigens for use in vaccines against $O$. volvulus.

Acknowledgment: We thank Raymond Cascarino for invaluable technical assistance.

Financial support: This work was funded by grants from the Edna McConnell Clark Foundation.

Authors' addresses: Anna Marie Lange, Wiboonchai Yutanawiboonchai, and David Abraham, Department of Microbiology and Immunology, Thomas Jefferson University, Philadelphia, PA 19107. James B. Lok, Department of Pathobiology, University of Pennsylvania, Philadelphia, PA 19104. Milan Trpis, Department of Immunology and Infectious Diseases, The Johns Hopkins University, Baltimore, MD 21205.

\section{REFERENCES}

1. Carlow CKS, Muller R, Bianco AE, 1986. Further studies on the resistance to Onchocerca microfilariae in CBA mice. Trop Med Parasitol 37. 276-281.

2. Carlow CKS, Dobinson AR, Bianco AE, 1988. Parasite-specific immune responses to Onchocerca lienalis microfilariae in normal and immunodeficient mice. Parasite Immunol 10: 309322.

3. Carlow CKS, Bianco AE, 1987. Transfer of immunity to the microfilaria of Onchocerca lienalis in mice. Trop Med Parasitol 39: 283-286.

4. Bianco AE, Luty A, Whitworth J, Taylor D, 1991. Immunity to Onchocerca volvulus microfilariae in mice and the induction of cross-protection with O. lienalis. Trop Med Parasitol 42: 188190.

5. Maizels RM, Kurniawan A, Selkirk ME, Yazdanbakhsh M, 1991. Immune responses to filarial parasites. Immunol Lett 30: 249-254.

6. Duke BOL, 1962. Experimental transmission of Onchocerca volvulus from a man to a chimpanzee. Trans R Soc Trop Med Hyg 56: 271.

7. Greene BM, 1987. Primate model for onchocerciasis research. Ciba Found Symp 127: 236240.

8. Soboslay PT, Dreweck CM, Taylor HR, Brotman B, Wenk P, Greene BM, 1991. Experimental onchocerciasis in chimpanzees: cell-mediated immune responses and production and effects of IL-1 and IL-2 with Onchocerca volvulus infection. J Immunol 147: 346-353. 
9. Soboslay PT, Weiss N, Dreweck CM, Taylor HR, Brotman B, Schulz-Key H, Greene BM, 1992. Experimental onchocerciasis in chimpanzees: antibody response and antigen recognition after primary infection with Onchocerca volvulus. Exp Parasitol 74: 367-380.

10. Eberhard ML, Dickerson JW, Boyer AE, Tsang VCW, Zea-Flores R, Strobert E, 1991. Experimental Onchocerca volvulus infections in mangabey monkeys (Cerocebus atys) compared to infections in humans and chimpanzees (Pan troglodytes). Am J Trop Med Hyg 44: 151-160.

11. Kozek WJ, Marroquin HF, 1982. Attempts to establish Onchocerca volvulus infection in primates and small laboratory animals. Acta Trop 39: 317-324.

12. Townson S, Bianco AE, Owen D, 1981. Attempts to infect small laboratory animals with the infective larvae of Onchocerca lienalis. J Helminthol 55: 247-249.

13. Suswillo RR, Nelson GS, Muller R, McGreevy PB, Duke BOL, Denham DA, 1977. Attempts to infect jirds (Meriones unguiculatus) with Wuchereria bancrofti, Onchocerca volvulus, Loa loa, and Mansonella ozzardi. J Helminthol 46: 132134.

14. Strote G, 1985. Development of infective larvae of Onchocerca volvulus in diffusion chambers implanted into Mastomys natalenis. Trop Med Parasitol 36: 120-122.

15. Bianco AE, Mustafa MB, Ham PJ, 1989. Fate of developing larvae of Onchocerca lienalis and $O$. volvulus in micropore chambers implanted into laboratory hosts. J Helminthol 63: 218-222.

16. Abraham D, Eberhard ML, Lange AM, Yutanawiboonchai W, Perler FB, Lok JB, 1992. Identification of surrogate rodent hosts for larval Onchocerca lienalis and induction of protective immunity in a model system. $J$ Parasitol 78 : 447-453.

17. Abraham D, Lange AM, Yutanawiboonchai W, Trpis M, Dickerson JW, Swenson R, Eberhard ML, 1993. Survival and development of larval Onchocerca volvulus in diffusion chambers implanted in primate and rodent hosts. J Parasitol 79: 571-582.

18. Tanner $M$, Weiss $N, 1981$. Dipetalonema viteae (Filariodea): development of the infective larvae in micropore chambers implanted into normal, infected and immunized jirds. Trans $R$ Soc Trop Med Hyg 75: 173-174.

19. Weiss N, Tanner M, 1979. Studies on Dipetalonema viteae (Filaroidea) 3. Antibody-dependent cell-mediated destruction of microfilariae in vivo. Trop Med Parasitol 30: 73-80.

20. Abraham D, Grieve RB, Mika-Grieve M, Seibert BP, 1988. Active and passive immunization of mice against larval Dirofilaria immitis. J Parasitol 74: 275-282.

21. Abraham D, Grieve RB, Holy JM, Christensen BM, 1989. Immunity to larval Brugia malayi in BALB/c mice: protective immunity and inhibition of larval development. Am J Trop Med Hyg 40: 598-604.
22. Rajasekariah GR, Monteiro YM, Netto A, Deshpande L, Subrahmanyam D, 1989. Protective immune responses with trickle infections of thirdstage filarial larvae of Wuchereria bancrofti in mice. Clin Exp Immunol 78: 292-298.

23. Hayashi Y, Noda K, Shirasaka A, Nogami S, Nakamura $M, 1984$. Vaccination of $B A L B / c$ mice against Brugia malayi and $B$. pahangi with larvae attenuated by gamma irradiation. Jpn J Exp Med 54: 177-181.

24. Yates JA, Higashi GI, 1985. Brugia malayi: vaccination of jirds with ${ }^{60} \mathrm{cobalt}$-attenuated infective stage larvae protects against homologous challenge. Am J Trop Med Hyg 34: 1132-1137.

25. Wong MM, Guest MF, Lavopierre MMJ, 1974. Dirofilaria immitis: fate and immunogenicity of irradiated infective stage larvae in beagles. Exp Parasitol 35: 465-474.

26. Oothuman P, Denham DA, McGreevy PB, Nelson GS, Rodgers R, 1979. Successful vaccination of cats against Brugia pahangi with larvae attenuated by irradiation with 14 krad cobalt 60 . Parasite Immunol 1: 209-216.

27. Chusattayanond W, Denham DA, 1986. Attempted vaccination of jirds (Meriones unguiculatus) against Brugia pahangi with radiation attenuated infective larvae. J Helminthol 64: 149-155.

28. Lucius R, Textor G, Kern A, Kirsten C, 1991. Acanthocheilonema viteae vaccination of jirds with irradiation-attenuated stage-3 larvae and with exported antigens. Exp Parasitol 73: 184 196.

29. Rao YVBG, Mehta K, Subrahmanyam D, 1977. Litomosoides carinii: effect of irradiation on the development and immunogenicity of the larval forms. Exp Parasitol 43: 39-44.

30. Fuhrman JA, Piessens WF, 1989. Filariasis. Liew FY, ed. Vaccination Strategies of Tropical Diseases. Boca Raton, FL: CRC Press, 219-238.

31. Prince AM, Brotman B, Johnson EH, Smith A Jr, Pascual D, Lustigman S, 1992. Onchocerca volvulus. Immunization of chimpanzees with $\mathrm{X}$-irradiated third stage $\left(\mathrm{L}_{3}\right)$ larvae. Exp Parasitol 74: 239-250.

32. Mehta K, Subrahmanyam D, Sindhu RK, 1981. Immunogenicity of homogenates of the developmental stages of Litomosoides carinii in albino rats. Acta Trop 38: 319-324.

33. Carlow CKS, Philipp M, 1987. Protective immunity to Brugia malayi in BALB/c mice: potential of this model for the identification of protective antigens. Am J Trop Med $\mathrm{Hyg}$ 37: 597-604.

34. Grieve RB, Abraham D, Mika-Grieve M, Seibert BP, 1988. Induction of protective immunity in dogs to infection with Dirofilaria immitis using chemically-abbreviated infections. Am J Trop Med Hyg 39: 373-379.

35. Eichner M, Renz A, 1990. Differential length of Onchocerca volvulus infective stage larvae from the Cameroon rain forest and savanna. Trop Med Parasitol 41: 29-42. 